\title{
From Dawson City to Regina Trench: How Joe Boyle's Mounted Yukoners Adapted to Fighting the First World War, 1914-1916
}

\author{
Cameron Pulsifer \\ Canadian War Museum (Retired)
}

\begin{abstract}
The Yukon Motor Machine Gun Battery, as it was officially titled as of 16 June 1916, began life in Dawson City in October 1914, as Boyle's Mounted Machine Gun Detachment. Its formation resulted from the coalescence of two factors: the interest of the Canadian Minister of Militia Defence, Sam Hughes, to have mobile machine gun units form a part of the emerging Canadian Expeditionary Force; and the willingness of the wealthy Yukon mining entrepreneur, Joseph Whiteside Boyle, to fund such a unit as an expression of his desire to contribute to the emerging Canadian war effort. With a strength of only fifty men, however, it was a small unit, and military authorities soon realized that mounted units like it would be of little use in the high intensity trench fighting of the Western Front. After its arrival in England in July 1915, its very existence became problematic for a time as authorities tried to figure out what to do with it. This paper explores the conditions that resulted in its survival and continued service when a need was found for motor machine gun batteries to serve with each of the four Canadian divisions. The Yukons were attached to the 4th Division, and in time became specialists in a form of machine gunnery that, while suited to the needs of the industrialized form of warfare that characterized that conflict, was no doubt a far cry from the idealized expectations of the unit's founders and original membership. This article is part of a special collection of papers originally presented at a conference on "The North and the First World War," held May 2016 in Whitehorse, Yukon.
\end{abstract}

The Northern Review 44 (2017): 139-162 
This article examines the origins of the Yukon Motor Machine Gun Battery and traces its struggle to find a role for itself within the Canadian Expeditionary Force (CEF). It was a near-run thing and they came close at times to extinction as a unit. By October-November 1916, however, the unit had found a role and mastered techniques related to the use of the machine gun, which would ensure its continued usefulness to the end of the war. This is the sense in which the unit adapted to fighting the First World War. The months that extended from August 1914 to the end of 1916 constitute a crucial period in the history of the unit, and hence the emphasis that is placed upon them here. This is a case study of how the sometimes high-flown expectations of enthusiastic early supporters of the war effort could become transformed by the harsh realities of the war as it was actually being fought.

The founding of the Yukon Motor Machine Gun Battery did not, of course, occur in a vacuum. It was, in fact, part of a mini-trend that formed a remarkable feature of Canada's emerging war effort. The deadly impact that the machine gun could have in warfare was amply demonstrated in the Russo-Japanese War of 1904-05, for those prepared to notice; but none of the powers that went to war in 1914 had any real comprehension of the huge role that the weapon would play in that conflict. Although it is unlikely that he foresaw this either, nonetheless something seems to have twigged with Sam Hughes, the Canadian minister of militia and defence from 1910 to 1916.

Hughes is usually excoriated by historians for his inefficient management of the Canadian war effort. ${ }^{1}$ But he did seem to perceive, from quite early on, that machine guns were an important weapon and that Canadian forces needed to be well-supplied with them. His perception of the weapon's importance may have stemmed from a 1912 visit that he and a number of Canadian militia officers made to the British Army's School of Musketry at Hythe in southern England. Hythe was then a hotbed of experimentation with the machine gun, carried out by specialists on its staff who had made a close study of the weapon's use in the Russo-Japanese War. The Canadians were clearly impressed by what they witnessed at Hythe, as is shown by the comments they made in a report compiled on the voyage home, and which, in 1914, was published as a parliamentary sessional paper. ${ }^{2}$

On his return to Canada, Hughes ordered from Britain a total of fifty Vickers machine guns. This weapon had been adopted only that year by 
the British Army as its standard model machine gun, replacing the older Maxim, by then deemed to be obsolete. The Vickers used the same basic operating system as the Maxim, but was lighter and was a better weapon in all respects. Indeed, it became the standard model heavy machine gun used by all British Empire forces in the First World War, and was to remain in use throughout the Second World War. The supply of Vickers ordered in 1912 not yet having arrived at the outbreak of war in August 1914, Canada found itself possessing a total of only forty-three workable machine guns, most of them obsolete Maxims. Hughes promptly ordered fifty more Vickers; but, due to their own rapidly expanding needs, the British informed him that neither these nor the fifty guns he had ordered earlier could be delivered. Hughes had no choice but to turn to the major North American manufacturer of machine guns, the Colt Patent Firearms Manufacturing Company in Connecticut, from which Canada had acquired a number of machine guns for use in the South African War of 1899-1902. The complicated Colt was nowhere near as reliable a weapon as the Vickers and generated much frustration among its Canadian users. But it was better than no weapon at all. The Canadian Expeditionary Force (CEF) went into its first major action, at the Second Battle of Ypres in 1915, reasonably well-equipped with the weapon, although the Colt company had great difficulty in meeting subsequent needs. ${ }^{3}$

Hughes was definitely ahead of his time in another matter having to do with machine guns - their use in a mobile role. To this end, within the first five months after the war's outbreak he leant his authority to the formation of four mobile machine gun units. Three of these were to be motorized, while one-that raised in the Yukon-was to be horsemounted. All were to be privately financed by wealthy Canadians. The first of the motorized units came into existence in late August, early September 1914. It was conceptualized and commanded by one Raymond Brutinel, an immigrant from France to the Canadian West who had an interest in the machine gun. Financing was arranged by Clifford Sifton, a former minister of the interior under Wilfrid Laurier, now involved in business and other ventures. The unit was made up of eight completely open, lightly armoured trucks, each with two machine guns mounted in the back (Fig. 1). Titled the Automobile Machine Gun Brigade No. 1, the unit went overseas with the First Canadian Contingent in October 1914. ${ }^{4}$ 


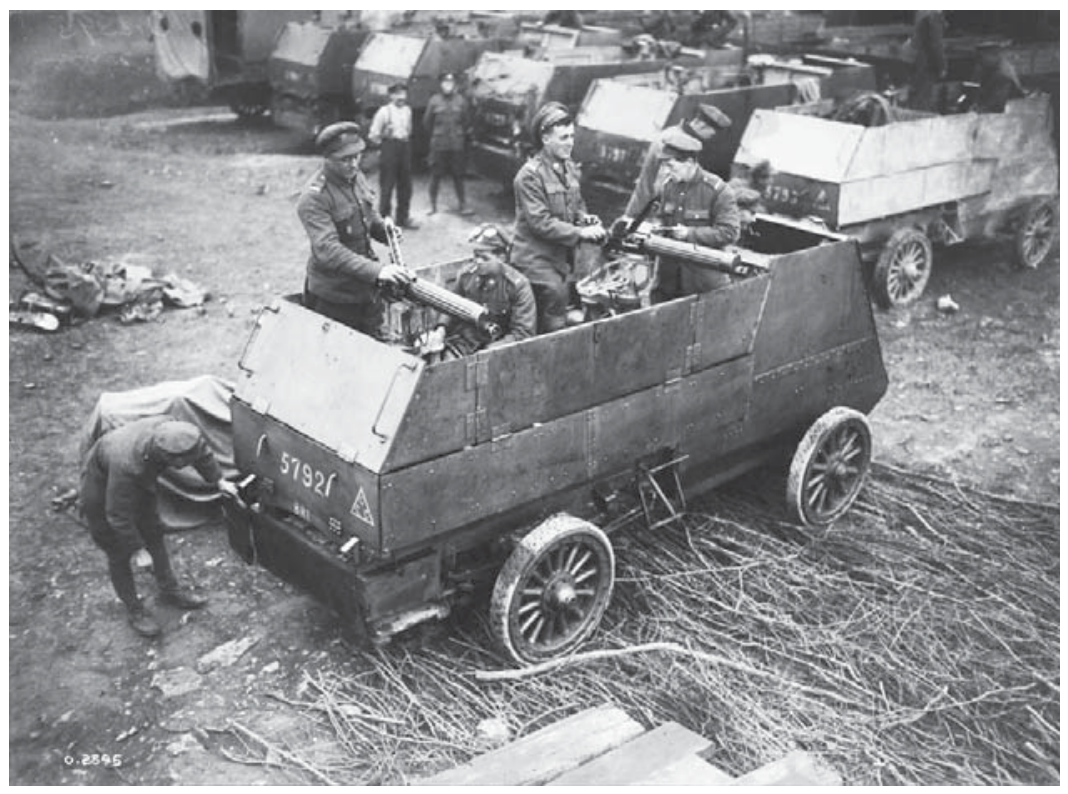

Fig. 1. Armoured Autocar, 1st Canadian Motor Machine Gun Brigade, Citadel, Arras, 1918. This is one of eight such vehicles that Raymond Brutinel took overseas in October 1914. Note the Vickers machine guns, which the unit received to replace their originally issued Colts, in August 1916. LAC Mikan3395368

The horse-mounted Yukon unit was the second to be formed. Its founder as well as funder was Joseph Whiteside Boyle of the Yukon (Fig. 2). Boyle was one of those larger-than-life characters that Canada seemed to produce in some abundance in the late nineteenth and early twentieth centuries. His major biographer, William Rodney, sums him up as a "sailor, entrepreneur, prizefighter, sourdough, intelligence agent and royal confidant." At the outbreak of war in August 1914, Boyle was at the height of his career as an industrial miner for gold in the

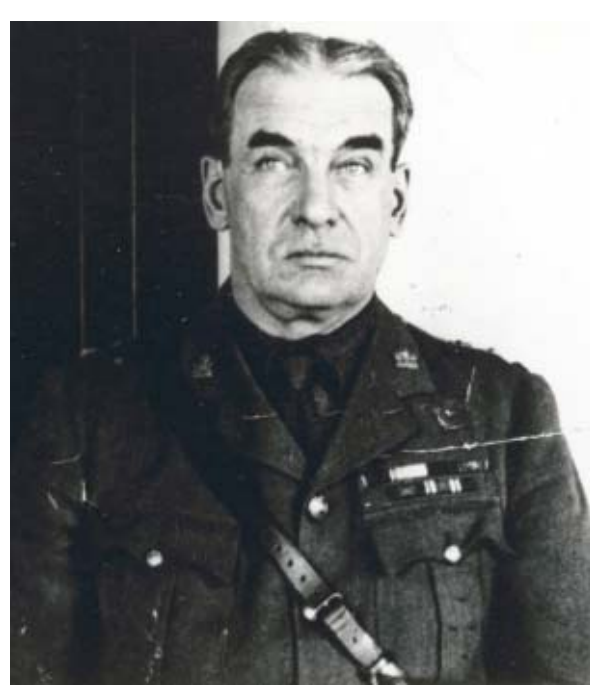

Fig. 2. Joe Boyle, ca. 1918, wearing the uniform of a Canadian Army colonel. Yukon Archives Klondike River. By means of four 
huge, electrically powered dredges positioned in the river, his Klondyke Mining Company was making him a fortune. ${ }^{5}$ At forty-seven years of age he was too old to enlist himself; but, an ardent Canadian and imperialist, he was keen to do something to help the emerging war effort. He informed Hughes of his desire in August, and the two agreed that Boyle's contribution should be organizing and financing a mounted machine gun unit consisting of fifty men, sixty horses, and four machine guns. With the cooperation of the Yukon Commissioner, George Black, and Superintendent J.D. Moodie of the local Royal Northwest Mounted Police, Boyle worked quickly. By 12 October he had the men recruited and ready to leave the Yukon for the long journey overseas. Pronouncing the new unit "the pride of the Yukon," the Dawson Daily News described its personnel as being outfitted, at Boyle's expense, in "natty new uniforms comprising khaki trousers and woolen shirts to match, yellow mackinaws, and stiff-brimmed sombreros [Stetsons]" (Fig. 3). ${ }^{6}$

Making its way by paddlewheel steamer to Whitehorse, the unit proceeded from there to Skagway, Alaska where it boarded ship for transport to Victoria, British Columbia. After a week's stay in Victoria, on 30 October the unit disembarked in Vancouver where it was to spend the next eight months. At Hastings Park in that city, the battery was attached to the $29^{\text {th }}$ Canadian Infantry Battalion, which was mobilizing at the park for service overseas. Over the next month, the men signed their attestation papers and were formally sworn in as members of the Canadian Expeditionary Force. This had not been done earlier in the Yukon, possibly, as is suggested in one source, because of concerns over having an officially constituted Canadian military unit passing through Alaska, a territory of the then neutral United States.

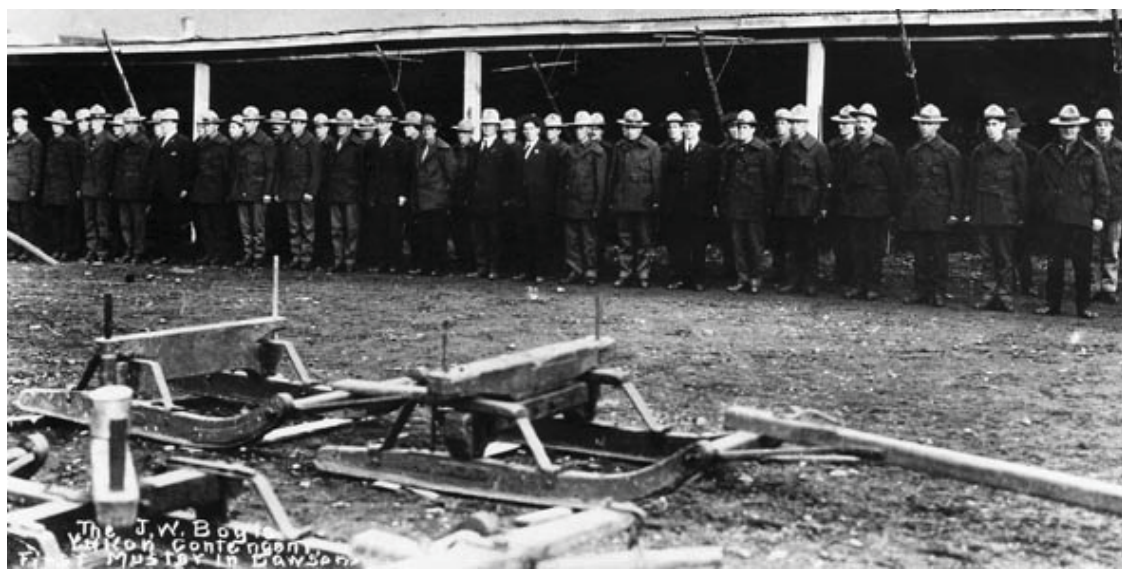

Fig. 3. J.W. Boyle's Yukon Contingent, First Muster, Dawson, October 1914. Yukon Archives. Oxford Historical Society \#112 
Sometime during the next couple of months, it is not certain precisely when, the unit, then at a strength of forty-eight, received its supply of horses-fifty-two to be mounts for the men and eight to be equipped with pack saddles to carry the machine guns. ${ }^{8}$ During a visit to the unit in January 1915, Boyle arranged for them to be further equipped with "Mexican stock saddles," Colt revolvers, nickeled spurs, and Hudson's Bay blankets. ${ }^{9}$ The term "Mexican stock saddle" was one used by Canadian stores personnel in England when they found they had to dispose of them after the Yukoners no longer had a use for them. The term almost certainly referred to the standard type of western stock saddle used universally by cowboys at the time (and in countless subsequent Hollywood films). This saddle was also the type used by the North-West Mounted Police of the era. Very likely, Boyle would have been inclined to emulate themNWMP Superintendent J.D. Moodie having helped with the formation of the unit. This most likely would have been the case with the type of Colt revolvers that the unit received as well, the New Service Colt being then the standard sidearm of the NWMP. ${ }^{10}$ The Hudson's Bay blankets, presumably for use as saddle blankets, would have been a unique touch.

Regrettably, none of the limited amount of correspondence that survives between Boyle and Hughes about the unit contains any real indication what precise role the two men envisioned it playing in the war. All we have is a statement made in October 1915 by Boyle's agent in London, one T.D. MacFarlane, that it was meant to be a "machine gun section of a Yeomanry Regiment."11 Historian William Stewart has pointed out that Yeomanry units and Mounted Rifles were essentially the same thing. They were "considered cavalry soldiers, also trained to fight mounted or dismounted, but with the rifle as their principle weapon"; they were also "part time soldiers and the army did not believe there was sufficient time to train them to cavalry standard for shock action." ${ }^{12}$

Mounted rifle units had become increasingly popular throughout at least the settlement colonies of the British Empire in the latter years of the nineteenth century. Large numbers of them served in the South African War, in which both sides made extensive use of mounted formations. Indeed, while Canada sent one battalion of infantry to that war, it despatched a total of seven units of Canadian Mounted Rifles (CMR). The perceived success of such units in that war prompted authorities to place an even greater emphasis on them afterwards, with Canada authorizing the creation of twenty-five new CMR units between 1901 and 1913. Although upon Canada's entry into the First World War its greatest emphasis fell upon the formation of infantry units, nonetheless, before the end of 1914, 
Canada had offered to send overseas no fewer than thirteen battalions of mounted rifles, as well. ${ }^{13}$

Still, there was a significant difference between CMR units and Boyle's mounted detachment. While all of the CMR units had a machine gun section, consisting of one officer and twenty-six other ranks to operate two guns, their primary weapon was the rifle. Conversely, while the men of Boyle's detachment did have rifles, their primary arm was to be the machine gun, of which they were supposed to have four, later six. Moreover, as it was twice the size of a standard CMR machine gun section, Boyle's creation was almost certainly meant to operate independently, as was the case with the three motorized machine gun units that Hughes authorized at the same time. This made Boyle's unit unique, certainly among Canadian units and possibly among those of the British Empire as a whole. Hence Hughes and Boyle were forward thinkers in conceiving an independent mounted unit armed exclusively with machine guns. On the other hand, it is clear that they were thinking that it would participate in a war similar to that fought in South Africa, where mounted units played an active part.

Boyle's mounted Yukoners were undergoing preparatory drills in Vancouver when, on 20 November, Hughes authorized formation of the third of the three mobile machine gun units and the second to be motorized. The gift of a number of wealthy Montreal businessmen, the unit was to be named after Prime Minister Robert Borden. To be composed of six officers and fifty-four rank and file, it was meant to operate six armoured cars made by Packard. These were to be completely armoured with their machine guns firing from centrally mounted turrets. ${ }^{14}$ Already, however, decisions were being made at higher levels of authority that would drastically affect the future of these units. By early December 1914 the British War Office was informing Ottawa that it no longer wanted any armoured car units. The trench lines had begun to form and British motorized units were spinning to a halt amid the shell holes and mud and goo that suffused the front. ${ }^{15}$ The men and weapons were needed; the armoured vehicles were not. In the end, when the officers and men of the Borden battery left Montreal for England on 17 May, they had no armoured cars (of which only one, a prototype, was ever made). Nor had they yet been issued with machine guns. ${ }^{16}$

Not to be fazed by the War Office, the obstinate Sam Hughes went ahead, on 31 December 1914, to authorize the formation of yet another force of armoured motor vehicles equipped with machine guns. ${ }^{17}$ This one, organized and recruited in Toronto, was financed by the department 
store magnate, John C. Eaton. The unit, as paid for by Eaton, was to consist of ten officers and ninety-one other ranks, who were meant to operate a total of fifteen armoured cars. Like those planned for the Bordens, these cars were to be much more formidable than those designed by Brutinel, which Canadian authorities were beginning to fear were too flimsy for service at the front. Like those of the Bordens, the cars of this so-named Eaton Brigade were completely enclosed by armour, their guns positioned in a centrally mounted turret. Hughes was so impressed that by the end of January 1915 he had authorized an increase in the number of armoured cars to forty and had augmented the unit's strength to twentyfive officers and 281 other ranks. These extras were to be paid for by the militia department. ${ }^{18}$ (Take that British War Office!) Nonetheless, as with the Bordens, when the Eaton Motor Machine Gun Brigade left for Great Britain in early June, they did so, like the Bordens, without their armoured cars, and with no machine guns.

Meanwhile, in Vancouver, the stay of Boyle's Yukoners at Hastings Park was becoming unduly protracted. While presumably attractively attired in the uniforms that Boyle had provided for them at Dawson City, and now in receipt of their horses, no machine guns had yet been issued. Nor was any information forthcoming from Ottawa as to when they were to proceed overseas. Boyle grew increasingly concerned and urged Hughes to take action. In the end, however, Boyle came to agree with arguments made by Hughes that, although it was meant to operate independently, the detachment was simply too small to be shipped overseas on its own. The two then came up with a solution to this problem. The $2^{\text {nd }}$ Canadian Mounted Rifles Regiment (2CMR) was also in Vancouver and slated to go overseas soon. Hughes and Boyle arranged for the Yukoners to be incorporated into $2 \mathrm{CMR}$ as its machine gun section, even though it was twice the allotted size. The unit's existing machine gun section would be carried as supernumeraries. The new arrivals would retain their Yukon identity and would resume their independent status upon arrival in England. ${ }^{19}$

The Yukoners joined 2CMR on 1 April. However thrown together the arrangement was, it seemed to work fairly well, at least for the Yukoners. An officer was put in charge, and they managed to gain some training on 2CMR's Colt machine guns. They did, however, give up wearing the uniform with which Boyle had outfitted them and instead adopted that worn by $2 \mathrm{CMR}$. This consisted of the approved Canadian khaki tunic of the day, khaki breeches, lace-up boots, with knee-high puttees, topped off with Stetson hats. In the well-known photograph of the Yukon detachment, 
taken in front of a large house bearing a placard reading "From Dawson to Berlin," the men, whose names are inscribed at the bottom, are, in fact, wearing the uniform of $2 \mathrm{CMR}$. This photo was taken in Vancouver (Fig. 4). ${ }^{20}$

A month later, with $2 \mathrm{CMR}$ and its recently-added oversized machine gun section still in Vancouver, the militia department made a decision that would significantly affect the future of both. The conditions of the Western Front were simply not suitable for the number of mounted units that Canada was preparing to send. Henceforth, the department ruled, CMR units would no longer be mounted and would instead serve as infantry. ${ }^{21}$ This no doubt lay behind Hughes's instructions made later that month to the effect that Boyle's detachment should go "overseas as a unit without horses." 22 When the Yukoners left Montreal for England on 1 July 1915, as part of 2CMR, they did so without their horses, which they would never see again. Also, while they had machine guns, these were the property of 2CMR.

After their arrival in England, Hughes's recently formed mobile machine gun units went from pillar to post, as authorities tried to figure out what to do with them. As originally planned, Brutinel's brigade went to the $1^{\text {st }}$ Division upon its arrival. But there were no similar affiliations available for the Bordens, Eatons, and Boyle's Yukoners. They had, however, come overseas at the same time as the $2^{\text {nd }}$ Canadian Division,

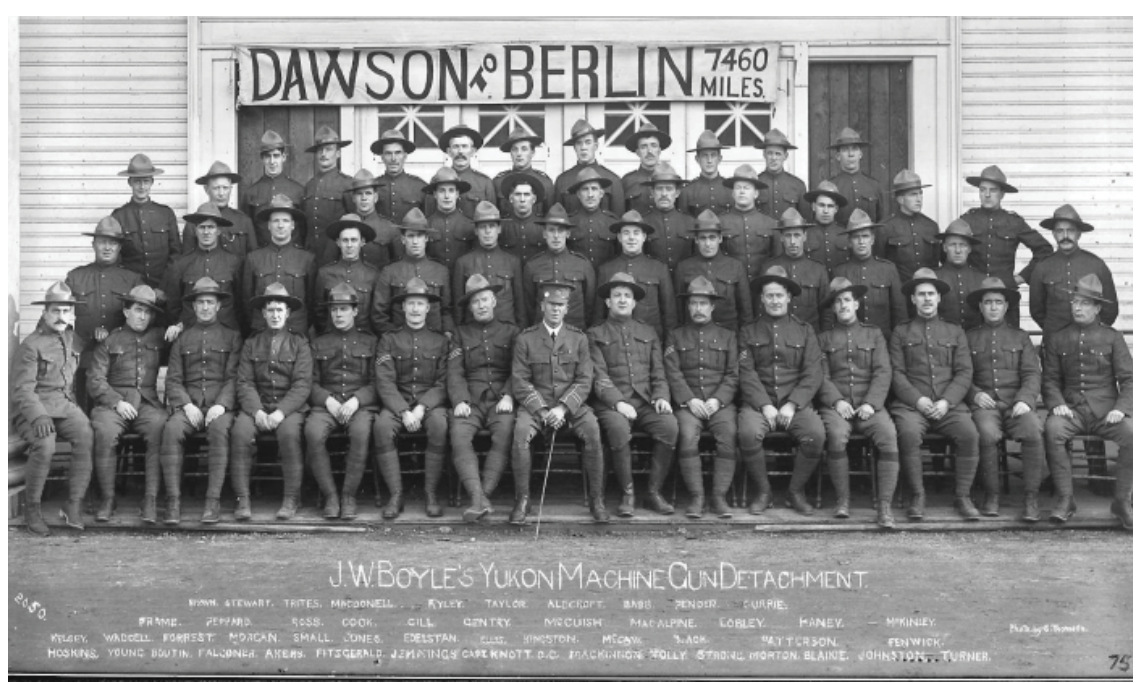

Fig. 4. J.W. Boyle's Mounted Machine Gun Detachment, wearing the uniform of the 2nd Regiment Canadian Mounted Rifles, Vancouver, Spring 1915. City of Vancouver Archives, Stuart Thompson fonds, item CVA-109 
and were all sent to Shorncliffe Camp in South East England where the $2^{\text {nd }}$ Division was mobilizing. But as there was no assigned spot for them in the two existing Canadian divisions, they were left almost completely adrift with hardly any formal arrangements in place for their training or indeed future use. As for the now independent Yukon detachment, it even found that it had to relinquish the machine guns the men had been using for the past three months, which were quite properly reclaimed by 2CMR. They also gave up wearing $2 \mathrm{CMR}^{\prime}$ s uniform. Instead of re-donning the uniforms provided for them by Boyle, however, much to their distress, and at the insistence of the commanding officer at Shorncliffe, the Yukoners were attired in the standard uniform of the Canadian infantry. This meant surrendering their mackinaws, Mexican saddles, Colt pistols, and Stetson hats, which were put into stores, never to re-emerge.

One of the duties of Boyle's agent in England, T.D. MacFarlane, was to attend to the unit's interests while it was in that country. MacFarlane made a proper nuisance of himself to authorities in pushing what he perceived to be the detachment's interests. But a measure of the difficulties that he and the detachment faced is shown by a letter written on 26 July 1915 by Hughes's senior representative in Britain, acting Major General J.W Carson, to Brigadier General J.C. MacDougall, the commanding officer at Shorncliffe: "Mr. Boyle seems to have raised a small unit of sixty [sic] and thinks that they are entitled to every sort of consideration," wrote Carson. "I have told Mr. Macfarlane [sic] that we simply cannot and will not treat them as a separate unit." ${ }^{23}$ MacDougall's solution was to attach the Yukoners to the much larger Eaton Motor Machine Gun Brigade, while allowing them to retain the title of "Boyle's Battery." MacFarlane "as well as the men of the battery" seem quite satisfied, wrote MacDougall, to which Carson replied that he "was glad you have everything running to the satisfaction of these very-hard-to-satisfy people." ${ }^{24}$

The men of Boyle's detachment spent the next seven months attached to the Eatons, and it was not a happy alliance. The military files from this period are full of expressions of discontent on the part of the Yukoners over being linked to the Eatons. They must have felt relatively dwarfed as part of the much larger Eaton Brigade, which, with twenty-four officers and 254 men, was almost six times as large. Furthermore, this large assemblage had only three machine guns of its own, which would have made for considerable competition in gaining access to them for training. In addition, the Yukoners believed the personnel of the Eatons to be haughty and disdainful towards them, with the result that the Yukoners viewed their association with the Eatons as a period in purgatory. 
In January 1916 the unit was at last furnished with a couple of officers, lieutenants F.A. Hale and C. Usborne. They came from the Eatons, however, so were unpopular and could not maintain discipline. The real sources of authority within the unit lay with a number of the noncommissioned officers (NCOs), in whose charge the unit had effectively been since its formation. Acting Sergeant Major Harold Strong, with five years of service in the NWMP and two years in South Africa behind him, seems to have been the leader. Sergeants Robert Morton and William Black also had influence. Morton was a former NWMP constable and miner. Black, who identified his civilian occupation as forest ranger, was the brother of the Yukon commissioner, George Black, and had also served in South Africa. The long-time quartermaster sergeant of the unit, James A. McKinnon, who seems to have taken special umbrage over the union with the Eatons, was another figure of authority. He exerted himself strenuously on behalf of securing the unit's independence from the Eatons. But he was hampered by the fact that, in November 1915, he was broken in rank for drunkenness and transferred to the Veterinary Corps for his sins. He blamed this lapse on the stresses incurred by his efforts to separate the Yukoners from the Eatons, however, and continued to press for reinstatement.

Boyle and MacFarlane thought highly of these men and believed them all to be more than capable of becoming officers. The consummate professional, Captain H.F. Meurling (Fig. 5), who took command of the unit in June 1916, held a different assessment. In his view, Black was the only one who "had the slightest conception of military discipline." ${ }^{25}$ As is clear in numerous vituperative letters that he wrote to Boyle, Meurling felt threatened by this cabal of non-commissioned officers and insisted upon appointing his own officers. Against his better judgement, however, he was persuaded by Boyle and others to make Strong a lieutenant. Both Strong and Morton proved to be major disappointments in the Battle of the Somme in November, and Meurling was retrospectively outraged over the pressure that had been brought to bear on him to

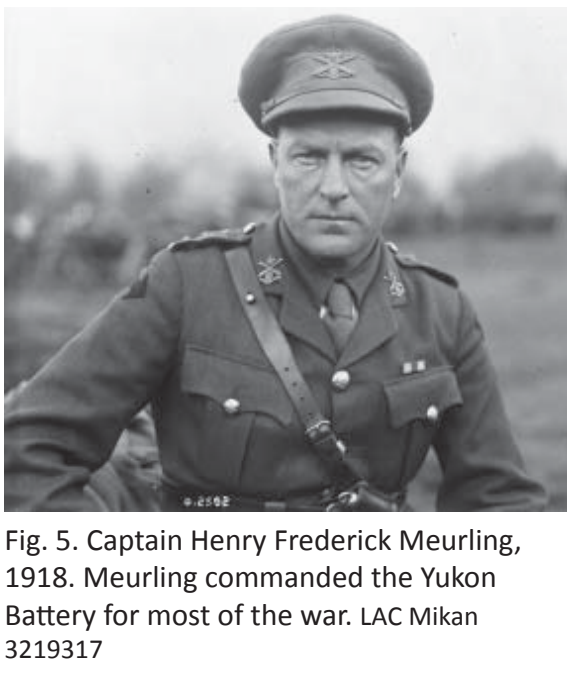


promote them. "Please ask all the old Yukoners of their opinion of Mr. Strong and Sergt. Morton now when they have been under fire," fumed Meurling in a letter to Boyle. No longer, he insisted, would he allow "any 'gasbags' work the ropes for their own benefit at the expense of those men who did the work." ${ }^{26}$ Nor did he have much use for McKinnon, who, he was convinced, continued to machinate behind his back. In the end, he promoted Black to the position of lieutenant that had been left vacant by Strong's prolonged departure from the Somme, due, he claimed, to myalgia. (It should be noted, though, that McKinnon did later succeed in rejoining the unit as a lieutenant and apparently gave it good service to the end of the war.)

In November 1914 the British Army had taken a step that would eventually have a profound impact on the future of Hughes's four mobile machine gun units. It approved the formation of a motor machine gun service of its own, to consist of batteries composed of four officers and fifty-four other ranks, equipped with six machine guns. The weapons were to be carried in the side cars of motorcycles. They received, in addition, a number of trucks for transporting gasoline, ammunition, and personnel. A single battery was allotted to each division. This action provided a precedent for Canadian authorities to follow. It almost certainly lay behind the sanctioned departure of Brutinel's brigade to join the $1^{\text {st }}$ Division at the front in June 1915. As it was composed neither of heavy armoured cars nor motorcycles, the British War Office did not know quite what to make of this unit and had not allowed it to accompany the $1^{\text {st }}$ Division when the latter proceeded to Flanders in February 1915. With pressure being exerted by Hughes from Ottawa, the War Office finally relented that June and, despite its unconventional composition, allowed Brutinel's brigade to join the $1^{\text {st }}$ Division as its motor machine gun unit. In conformity with British usage, it bore the new title of $1^{\text {st }}$ Canadian Motor Machine Gun Brigade. $^{27}$

Also in line with the British precedent, in September the Bordens were equipped with motorcycles, machine guns, and the requisite number of trucks, and proceeded to the front as the motor machine gun battery of the $2^{\text {nd }}$ Canadian Division. ${ }^{28}$ The trend continued when, in February 1916, the Eatons were made the motor machine gun battery of the recently formed $3^{\text {rd }}$ Canadian Division. It must have come as a mixed blessing for them, however, as they had to surrender their brigade status, and, in line with the established strength of a motor machine gun battery, saw their strength slashed to four officers and fifty-four other ranks. ${ }^{29}$ 
For the Yukoners, this meant that they had at last obtained independence. Their strength had by then dwindled to thirty-five, however, owing to the departure of men seeking more active employment in other units. The temptation must have been felt in some quarters simply to disband the detachment and use the personnel elsewhere. But despite its diminished size, it was kept together as a separate unit. No doubt under pressure from Boyle, Hughes remained an influential backer of its continued existence. In addition, the unit had an influential backer in England, Major General Samuel Benfield Steele, an old friend of Boyle's from the Yukon, who had come to England in May 1915 as commander of the $2^{\text {nd }}$ Canadian Division. ${ }^{30}$ However, the storied NWMP officer and military commander, then aged sixty-six, was judged by the British Secretary of State for War, Lord Herbert Kitchener, to be too old to command in the field. Instead, Major General R.E.W. Turner received the command of the $2^{\text {nd }}$ Division, with Kitchener rewarding Steele by appointing him to an imperial post as commander of troops in southeast England, which included Shorncliffe. Soon afterwards, not to be outdone by the British, Sam Hughes further complicated the Canadian command situation in England by appointing Steele commander of all Canadian troops in that country, not apparently concerned that in this role his responsibilities conflicted with those of Carson in London and MacDougall at Shorncliffe.

Steele therefore retained considerable influence, and clearly was prepared to use it in the best interests of Boyle's Yukon detachment. The existing documentation contains many examples of his intervening on its behalf. For example, in a note Steele sent to MacDougall on 15 January 1916, he argued: "Mr. Boyle would naturally like his patriotism rewarded by the Yukon battery being sent to the front," he wrote.

Will you please have the Battery specially looked to with a view to their being sent to the front at the very first opportunity. If it is not up to strength there are numbers of Western men (if not from the Yukon) of the right type who could be transferred to it. Will you please let me know exactly how the Battery stands? ${ }^{31}$

A month later he underlined his support for the unit by assuring Boyle that he would "look after interests of Battery. ${ }^{32}$

Hughes weighed in, as well, informing Carson that the unit must be "kept intact." 33 Despite the pressure being exerted from above, however, Carson and MacDougall proceeded cautiously. Part of the problem for them in sorting out what to do with the detachment may have had to do 
not only with its relatively small size, but also with the fact that it was still identified as a mounted unit for which there were far fewer service options. After a second and more emphatic intervention by Hughes in early April, deploring the pair's continued inaction, Carson and MacDougall's first thought was to attach the unit to the Canadian Cavalry Brigade. As a result, the Yukoners were sent to the Canadian Cavalry Depot then located at Bulford near Salisbury Plain, presumably to be ready should an opening occur. ${ }^{34}$

But by then the $4^{\text {th }}$ Canadian Division was in the process of formation at Bramshott Camp, just south of Aldershot in Hampshire. It had not yet been equipped with a motor machine gun battery. Sam Steele, for one, believed that role should be filled by the Yukons (as the detachment was increasingly becoming known). Whether, in the end, he influenced the decision is not known, but on 7 May MacDougall made a point of informing him that the decision had been taken to make the Yukons the motor machine gun battery for the $4^{\text {th }}$ Division..$^{35}$ Approval from the division came five days later, with official authorization coming from the War Office on 25 May. A note of incredulity is apparent in the latter's observation that "the Yukon Battery of whose existence the War Office was not aware, will be a welcome asset." 36

As with the Bordens and the Eatons, once the decision was made matters moved very quickly. The unit was now officially titled the Yukon Motor Machine Gun Battery. On 16 June, a commanding officer was appointed in the formidable person of Captain Henry Frederick Victor Meurling. One of his first moves was to dispense with the services of Lieutenants Hale and Usborne, and arrange for the appointment of two men in their place who had served under him previously and whom he knew to be bright and capable. At his urging, Sergeant W.G. Nicholson and Corporal R.D. Harkness, then serving at the front, were awarded commissions as lieutenants and brought to England to join the Yukons. To bring the unit's required strength up to fifty-four, additional personnel began to arrive almost immediately, mostly from the $82^{\text {nd }}, 87^{\text {th }}$, and $89^{\text {th }}$ battalions and from the Canadian Army Service Corps.

At this point, it is appropriate to consider the makeup of the unit that emerged from these renovations, which, of course, was its composition when it went into action in France. A couple of nominal rolls, one completed in July and the other in November 1916, allow for such a profile to be compiled.$^{37}$ First, it should be noted that the stereotype of the Yukon Motor Machine Gun Battery is that it was composed largely of the kind of men that had come north in the gold rush of 1898: tough, self-reliant, 
determined, accustomed to a hard scrabble life of prospecting on the frontier. But what was the situation in the unit as it proceeded to France with the $4^{\text {th }}$ Canadian Division?

In fact, these nominal rolls show that there were, by then, two main groups in the unit. Of the original forty-six Yukoners who had come overseas, a total of twenty-seven, or just over half, remained. Twenty-five non-Yukoners had come in, both to replace those who had left and to bring the unit up to the required strength of a motor machine gun battery. Comparing the two groups makes for some interesting contrasts. The average age of the first, or original Yukon group, was older than the CEF as a whole, which was 26 years on enlistment. ${ }^{38}$ The average age of these original Yukoners was 33, the oldest being 42, the youngest 22. The second group, or the later arrivals, were more in line with the CEF average, the oldest being 27, the youngest 18, the average age being 24 .

The places of birth for the men in both groups also varied somewhat from the norm. Most were Canadian born, while it is well known that as many as $70 \%$ of the strength of the Canadian Expeditionary Force, as a whole in these early years, was British born. ${ }^{39}$ Indeed, in the first group, a total of eighteen, or $66 \%$ of the total, were Canadian-born. In the second, thirteen, or 54\%, were born in Canada. What explains this phenomenon is not readily apparent, at least to this researcher. In the first group, six, the largest concentration, came from Ontario, followed by four from Nova Scotia, and three from Prince Edward Island. One each came from British Columbia, Quebec, New Brunswick, and Newfoundland. Of the foreign born, four came from England, three from Scotland, one from Ireland, and one from the United States. In this respect, the notion that the original unit was composed mostly of northerners or westerners is called into question, as only one originally hailed from these regions. Of course, many may have lived and worked in the North for some time and self-identified as northerners, but this is impossible to determine from the sources used here. Indeed, the second group had more western born, with three each from Alberta and Manitoba, and one from British Columbia. (Were these the "Western men" Steele had mentioned?) Of the remainder, five came from Ontario and one from Nova Scotia. Of the foreign born, five came from England, two from Scotland, and one from Ireland. Somewhat exotically, perhaps, one was from Russia and another from Bombay, India.

But in one important respect the stereotype usually applied to the Yukon battery's original enlistees is largely correct. No less than fourteen of their number, or about half, identified themselves as miners or prospectors. Also, seven others listed themselves as labourers or with 
no trade or calling, and three as teamsters - all trades that could well have been associated with the field of mining. In addition, three identified themselves as metal workers, and one each as a surveyor, linesman, and clerk. One who ran significantly counter to type was Sergeant Frank McAlpine, of Prescott, Ontario, who identified himself as a broker! Even more remarkable, perhaps, was the number of these men who had previous military experience, some considerably so. In all, nineteen, or $70 \%$ of the total, had served previously either in the North-West Mounted Police or the military. Seven had served in the NWMP, three for five years, and one, Private Walter Oliver, for twenty-one years. Five had served in the South African War and one in the Spanish-American War.

The occupations listed by the second or late arrivals group, constituted a much wider representation of the trades and other occupations of the era, and none dominated as did the mining or prospecting fields in the first group. Most, in fact, seemed to have been skilled tradesmen. The largest single representation stemmed from fields that could well have been drawn to a unit that was by then, or was slated soon to be, motorized. Included were five chauffeurs, one auto-mechanic, one machinist, and one garage owner. There were also three teamsters, plus single representatives of such fields as plumber, electrician, carpenter, blacksmith, and painter. Two students and two farmers made up the group's tally. Only three had what they called previous military service. Only one, however, had experience that could in any way be considered serious-Private John Casanove, who had served three years in the $5^{\text {th }}$ (British Columbia) Regiment Canadian Garrison Artillery in Victoria, BC.

Special attention also needs to be to be paid to the Yukon battery's commander, Meurling. He occupied a very critical position for shaping the Yukon battery's future and, indeed, he was to command it, through a number of reorganizations, for pretty much the rest of the war. Five feet seven inches tall, with brown hair and blue eyes, he was the one who would turn it into a proper machine gun unit, and, moreover, make its members early specialists in a new and complex form of machine gunnery. This would, in due course, become the dominant means of using the weapon, at least in the armies under British command, on the Western Front. Born in 1875 in Sweden, Meurling trained as a civil engineer and served as an officer in the Swedish navy. He later served for a time with Belgian forces in the Congo before immigrating to Canada in about 1909. Settling in Nelson, British Columbia, he worked as an engineer for the federal government on Columbia River related water projects. He enlisted on 31 May 1915, at Sherbrooke, Quebec, in the $5^{\text {th }}$ Canadian Mounted Rifles. ${ }^{40}$ 
While serving in the Swedish navy, Meurling had gained considerable experience with machine guns. As a result, as soon as he joined 5CMR he was made its machine gun officer and went to Britain with the unit as such in July 1915. But once in England he was taken on as a machine gun instructor at the Canadian Military School in Shorncliffe. Here he demonstrated his expertise by inventing a special protractor to be used with Vickers guns in the firing of barrages, and publishing a small book based on his lectures, Machine Guns as Light Artillery. Hence, Meurling was something more than a standard machine gun officer. He knew the weapon intimately and had advanced notions about how it should be used. Indeed, he claimed, with much exaggeration, that he was the "first officer to take up and perfect the instruction in what is now known as indirect fire, by machine guns." ${ }^{41}$ He was, in fact, one of a small but growing group of officers within the British forces on the Western Front, including Raymond Brutinel, who pushed this notion. These officers argued that heavy machine guns, such as the Vickers and the Colt (Figs. 1 and 6), were much too heavy and unwieldy to be used in great numbers on the battlefield alongside the infantry, which is where they had been mostly positioned during at least the war's first year.

Meurling and the other "machine gun radicals" argued that the role of front line automatic weapon could best be filled by the Lewis gun, which was coming into increasingly frequent use by the time he arrived overseas. Compared to the $48 \mathrm{~kg}$. that a tripod-equipped Vickers weighed, the Lewis weighed only $12 \mathrm{~kg}$. It had only a small bipod, and could be carried over the mud-soaked, shell-hole-pocked battlefield with relative ease by a single infantryman. With a forty-seven-round drum magazine, which could easily be changed for another, it could provide an effective volume of automatic fire in such circumstances. The proper and most effective position for the heavier type of automatic weapons, these officers maintained, was in positions behind the front lines, firing over the heads

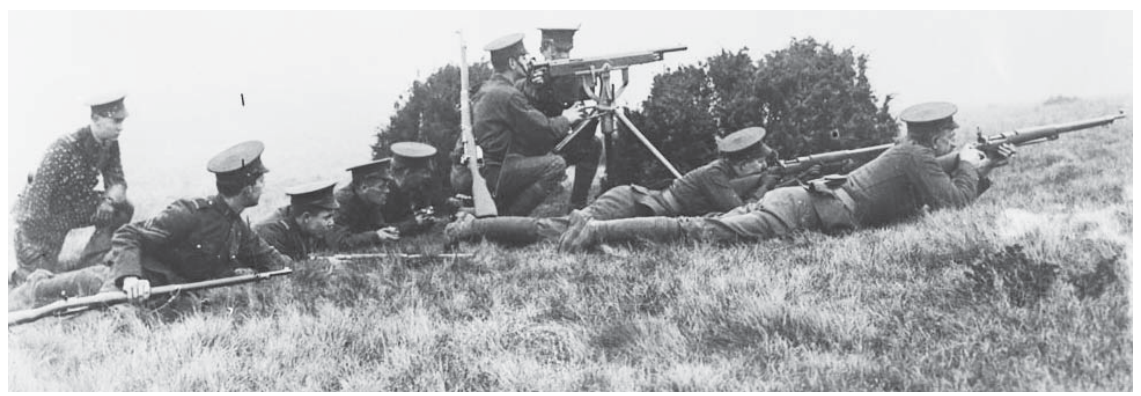

Fig. 6. Canadian troops manoeuvering a Colt machine gun in training in England, 1915. LAC Mikan3404365 
of their own troops in the trenches against targets behind the German front trenches. Thus situated, the weapons could be solidly positioned on the ground, which could not be done in the thick of the action, and which was essential if they were to be truly effective. Only from these rearward positions could they fire the massive quantities of ammunition that they were capable of expending over long periods of time during both day and night. ${ }^{42}$ Their targets would be enemy troop concentrations, work parties, local command centres, and generally making life in these critical rearward areas as dangerous as possible.

Meurling certainly was not an easygoing individual. Indeed, from the correspondence of his that survives, he comes across as prickly and argumentative. Nonetheless, in exercising command of his unit, the record shows him to have been an outstanding frontline officer. He was hard working, knew his craft thoroughly, was mathematically and tactically astute, and diligent at recording lessons learned. He certainly saw himself as the true expert in all the matters in which his battery was involved and key to whatever successes it had. But he was also of the school that believed one of the first duties of a commander was to ensure the welfare of those serving under him. He was well-respected by his troops, and the main targets in his often ill-tempered correspondence were those he considered to be shirkers, or who took undeserved credit for the accomplishments of others. Indeed, it is probably not going too far to claim Meurling as one of the Canadian Corps' unsung heroes.

Upon their arrival at the front in the Ypres Salient in July, the Yukons were issued with Vickers machine guns, which meant that, unlike the other three motor machine gun units that had come earlier, they never had to use the problematic Colt in action. They entered the line in early September, and the reports in the War Diary show that they immediately began to practice the tactics favoured by Meurling. By 30 August, however, the other three Canadian divisions had left the Ypres area for the Somme, some fifty kilometres to the southeast. Here they were to be caught up in fighting that was even more ferocious than what they had encountered at Ypres. Indeed, the Somme is a name that still resonates as one of the more grisly battles in human history. By the time the Canadians arrived, British forces had completed a slow and bloody slog to the area of Thiepval Ridge. The Canadians kicked off their stay in this area with a victory by taking and holding the village of Courcelette to the east of the ridge on 15 September. Thereafter until the end of the battle, as part of larger British assaults, the corps' objective remained a series of German trenches and redoubts that scored a low ridge to the west and north of 
Courcelette. Their ultimate objective was the farthest distant, the largest and best defended of these, named by the Canadians "Regina Trench."

Regina Trench remained stubbornly in German hands when the $4^{\text {th }}$ Canadian Division, accompanied by the Yukons, arrived at this sector of the Front on 2-3 October. It remained the division's major objective, when, after the departure from the Somme of its three senior Canadian divisions on 17 October, they remained as the lone Canadian formation fighting on that corpse-strewn battlefield. Working in conjunction with $2^{\text {nd }}$ British Corps to their left, their primary objective remained the capture of Regina Trench. With the blessing of the Canadian Corps commander, Sir Julian Byng, and the $4^{\text {th }}$ Division's commander, Major General David Watson, Meurling and his unit were to employ overhead, indirect fire and barrage techniques for the duration of their stay. Their motorcycles and other vehicles, it should be noted, were used only to transport them as close as they could to the site where their weapons would be set up. The guns were then carried to these positions either by man, horse, or mule power.

The division made its first assault on Regina Trench on 21 October. Accompanied by an even more intensive artillery barrage than had been used in previous attempts, its units were at last able to penetrate the enemy's barbed wire in significant numbers. Troops of the 11th Infantry Brigade captured a sizable length of the western portion of Regina Trench, and proved capable of holding it against enemy counterattacks. For this assault Meurling and the Yukons had twelve extra guns added from the division's three machine gun companies. Each gun was supplied with twenty filled-belts amounting to 5,000 rounds each, while belt-filling machines in place for every two guns were kept busy ensuring that extra belts were available when required. The gunners' principle role was "the creation of a barrage to close the valley" behind Regina Trench. ${ }^{43}$ The Yukoners' orders were for the guns to open up at Zero Hour

with rapid intense fire, which is applied for 20 minutes. For the next 40 minutes fire is applied at the rate of two belts [250 rounds each] every five minutes. At 1:06 p.m. fire is slackened to one belt per five minutes. For two periods of ten minutes fire is increased to two belts in order to break up an enemy counter attack .... Fire is applied during the night to hollows from which attacks are expected all night. ${ }^{44}$

In all, Meurling's machine guns fired 300,000 rounds $-90,000$ in the first twenty minutes of the attack. ${ }^{45}$ As noted, the operation was a success, with the Yukons rating the following complimentary reference in the 
diary of Major General Watson: "The [Bosche] made a couple of futile counter attacks yesterday, but all easily repulsed. Capt. Meurling with his M.G. Battery did splendid work." ${ }^{46}$ Indeed, a week later Watson placed Meurling in command of all $4^{\text {th }}$ Division machine guns.

Another attempt on 25 October failed. But for the next assault, 10-11 November, the Canadians made sure everything was ready. Artillery pulverized the section of Regina Trench being attacked, leaving it little more than a furrow in the ground. ${ }^{47}$ By mid-afternoon the attacking troops had their objectives secured. Meurling again had eighteen machine guns under his command for the attack, their role being identical to that of 21 October. A total of 72,000 rounds were fired from 1:30 to 2:30 in the afternoon of 10 November and 130,000 rounds from 4:30 to 8:00 p.m. Firing at a "light" rate was maintained from 11:00 p.m. to midnight and then at at "heavy" rate until dawn. In total, 530,000 rounds were expended. ${ }^{48}$

The $4^{\text {th }}$ Division undertook one last military operation on the Somme on 18 November. This time, they attacked Desire Trench, which lay about 640 metres north of Regina Trench. The centre of the attack experienced considerable success, not only moving into Desire Trench, but considerably beyond to the next major trench system. This time Meurling had no less than forty guns under his command, requiring eleven officers and 250 other ranks to operate. Clearly, $4^{\text {th }}$ Division commanders had concluded that machine guns used in the manner favoured by Meurling benefited their attacks. With British failure further north, however, and the weather drastically deteriorating, Sir Douglas Haig, the British commanderin-chief, at last determined that it was time to bring the fighting on the Somme to a halt.

The $4^{\text {th }}$ Division and the Yukons left the Somme on 30 November to join the rest of the Canadian Corps in the relatively quiet Arras sector. The CEF's official historian comments that while there, they had won their "spurs" as fighting units. ${ }^{49}$ Under the tutelage of Meurling, the Yukons had become skilled practitioners of what its exponents termed "scientific machine gunnery." This required the precise calculations of distances, heights, and angles, and also the use of carefully worked-out range charts. Such instruments of the surveyor as protractors, clinometers, and prismatic compasses became essential. The techniques learned on the Somme were essentially similar, albeit with some increase of refinement and sophistication, to those employed by Canadian machine gunners at Vimy Ridge in April, Hill 70 in August, and Passchendaele in OctoberNovember 1917. (It should be noted that Meurling was by no means alone in adopting such techniques. During the earlier stay of the three more 
senior Canadian divisions on the Somme, Raymond Brutinel had practiced them extensively with his 1st Canadian Motor Machine Gun Brigade, with the corps commander, Byng, placing numerous other of the corps' machine gun units under his command for the purpose. Brutinel would indeed be the one to go on to ensure that such tactics would be become the principal methods by which heavy machines were used within the Canadian Corps from Vimy Ridge on. Meurling would become one of his principal subordinates.)

In March 1918, of course, the Yukon contingent became involved in more actively-mobile operations when, as part of the $1^{\text {st }}$ Canadian Motor Machine Brigade, they again journeyed to the Somme to participate in fighting against the great German offensive that had recently been unleashed against British forces in that area. In June the unit was incorporated as " $\mathrm{A}$ " Battery into the $2^{\text {nd }}$ Canadian Motor Machine Gun Brigade, which before long came under the command of Meurling. Equipped with unarmoured "fighting" trucks, each equipped with two Vickers machine guns, the Yukons continued to be involved in mobile operations until the end of the war in November. This period in the unit's history demands treatment in a separate paper. But it can be said that it often involved the trucks manoeuvering the men and the machine guns into positions from which they could emit indirect and barrage fire against strongly held enemy positions. The Canal du Nord in October 1918 was a notable example, while later on the same techniques were frequently used to clear pockets of retreating, but still dangerous, enemy soldiers.

As founded, the Yukon unit was meant to participate in operations where mobile, horse-centered tactics would play a prominent part, as in the South African War of a decade and a half earlier. Instead, it found itself caught up in a much higher intensity and more stationary mode of conflict. Above all, Boyle's Yukoners had become agents of the steady and relentless application of firepower that, with machine guns playing a subordinate role to artillery, became a critical feature of the Allied mode of attack, and which would prove to be one of the critical elements that helped to break the back of the German Army in the world's first heavily

industrialized war. For the Yukons it was indeed a long way from the mounted horsemen ideals nourished in Dawson City and Vancouver.

\section{Author}

Cameron Pulsifer, PhD, is an historian who worked at the Canadian War Museum in Ottawa from 1991 to 2007 when he retired. 


\section{Notes}

1. Two major critiques are: Tim Cook, The Madman and the Butcher: The Sensational Wars of Sam Hughes and Arthur Currie (Toronto: Allen Lane Canada, 2010); Desmond Morton, A Peculiar Kind of Politics: Canada's Overseas Mission in the First World War (Toronto: University of Toronto, 1982).

2. Report of the Militia Council of the Dominion of Canada, 1913, Sessional Paper 35, 114-141 (Ottawa: King's Printer, 1914), 114-143.

3. See Cameron Pulsifer,"The Great Canadian Machine Gun Mania of 1915: The Public, the Press, and Government Decision Making in Procuring Machine Guns for the Canadian Expeditionary Force," Histoire Sociale/ Social History, vol. XLVI, No. 91 (mai/May 2013): 91-120. For Canadian assessments of the relative value of the Colt and the Vickers machine guns, see Bill Rawling, "Technology in Search of a Role: The Machine Gun and the CEF in the First World War," Material History Review, 42, 1995: 87-100.

4. Cameron Pulsifer, "Canada's First Armoured Unit: Raymond Brutinel and the Canadian Motor Machine Gun Brigades of the First World War," Canadian Military History, vol. 10, no. 1, winter 2001: 44-57.

5. William Rodney, "Boyle, Joseph Whiteside," in Dictionary of Canadian Biography, vol. 15, University of Toronto Press/Université Laval, 2003, accessed 21 Mar 2016, http://www.biographi.ca/en/bio/boyle joseph whiteside_15E.html. See also the same author's Joe Boyle: King of the Klondyke (Toronto: McGraw Hill-Ryerson, 1974), 95-101.

6. Ibid., 104.

7. See Lewis Green, The Gold Hustlers (Anchorage: Northwest Publishing Co., 1977), 214.

8. Library and Archives Canada (LAC), RG 9 III B1 Ser. 2 Vol. 731 File M-7-2 Vol. I, T.D. MacFarlane (for Boyle) to Maj. Gen. J.W. Carson, 26 Jul 1915.

9. LAC RG 9 D1 vol. 4687, folder 39 file 1. [Capt. H.F Meurling], "Yukon Machine Gun Battery."

10. For more on these items, see "Uniforms and Equipment of the Royal Canadian Mounted Police," accessed 26 Jul 2016, http://www.rcmp-grc. gc.ca/en/uniforms-and-equipment.

11. LAC RG9 III B1 Sec. 2 vol. 731 file m-17-2 vol. 1, T.D. MacFarlane to Major Morrison, O.C. Eaton Brigade, 9 Oct 1915.

12. William F. Stewart, "The Barrier and the Damage Done: Converting the Canadian Mounted Rifles to Infantry, December 1915," Canadian Military History 24, no. 1 (Winter/Spring): 286.

13. All this information is from ibid., 289-291.

14. LAC Sir Robert Borden Fonds, vol. 47 0c210-0c216, H.B. Meredith, Montreal to Borden, 18 Nov 1914, 21747-21747; LAC RG24 vol. 1354 HQ 593-3-28, Adjt. Genl. to O.C. 4th Division, Montreal, 18 Jan 1915.

15. Ibid. Sir William Harcourt, Colonial Office, to the Duke of Connaught, Governor General of Canada, 4 Dec 1914. 
16. Ibid., Adjt. General Canadian Militia to GOC Canadian Division, Shorncliffe Camp, England, 17 May 1915.

17. LAC RG 24 vol. 6533 HQ 640-1-4, vol. I, Adjt. Gen. Canadian Militia to GOC 2nd Canadian Division, Toronto, 3 Dec 1914.

18. Ibid, O.C. 2nd Div. to Secretary Militia Council, Ottawa, 22 Jan 1915.

19. LAC RG24 vol. 23885, Maj. W.E.L. Coleman, Officer in Charge of Records, Adjt. General's Dept., Canadian Militia, to Miss Fiona Boyle, 8 Sep 1930.

20. The author would like to thank uniform and regalia specialist, Tim Popp, for his help in confirming that the uniform was indeed that of $2 \mathrm{CMR}$. The photograph in question can be found on the website of the Vancouver City Archives: http://www/http:searcharchives.vancouver.ca/j-w-boylesYukon-machine-gun-detachment-with-names. Stewart Thomas fonds, CVA 99-1098. A published sources that reproduces the photograph is Green's The Gold Hustlers, 214-215.

21. See Stewart, "The Barrier and the Damage Done," 293.

22. Rodney, Joe Boyle, 107.

23. LAC RG 9 A-1 Ser. 8 vol. 47, file 8-5-40, Maj. Gen. J.W. Carson to Brig. Gen. J.C. MacDougall, 26 Jul 1915.

24. LAC RG 9 III A-1 ser. 8, Maj. Gen. Carson to Brig. Gen. J.C. MacDougall, 2 Aug 1915 and 26 August 1915; MacDougall to Carson, 28 Jul 1915.

25. LAC RG9-C-4 vol. 4350, Correspondence Book Y, Yukon Motor Machine Gun Brigade, Capt. H.F. Meurling to Joseph Boyle, 5 Dec 1916.

26. Ibid.

27. LAC RG24 vol. 1825 G.A.Q. 9-5, “Authority for Change of Designation from Auto M.G. Bde. No. 1 to 1st C.M.M.G.Bde," 16 May 1915.

28. LAC RG9-III-3 vol. 4387 file 630, War Diary, Borden Motor Machine Gun Battery, Aug-Sep 1915.

29. LAC RG9 III A-1 ser. 8 vol. 43 file 8-5-5, "General Canadians," Shorncliffe [MacDougall] to Carson, 25 Feb 1916.

30. Rodney, Boyle, 35.

31. LAC RG9 vol. 731 M-\&-2 vol. 1, S.B. Steele to G.O.C. Training Div. [MacDougall], 15 Jan 1915.

32. Rodney, 112.

33. LAC RG9 III vol. 47 A-1 Series 8 File 8-5-40, Hughes to NOSRAC [Carson], 26 Feb 1916.

34. Ibid. A.A. \& Q.M.G office, Shorncliffe, for Brig. Gen. MacDougall to Carson, 12 Apr 1916.

35. Ibid. Steele to MacDougall, 8 May 1916.

36. LAC RG9 C4 vol. 4345 Folder 4 File 2, Maj. R. W. Whigham, War Office, to Carson, 25 May 1916. Emphasis not in original. 
37. LAC RG9 III C-4 vol. 4350 Folder 2 File 18, Nominal Role, Yukon Motor Machine Gun Battery, 24 Jul 1916; LAC RG9 C-4 vol. 1430, Correspondence Book, Y5, Yukon Motor Machine Gun Battery, Daily Orders, 28 Nov 1916. By the time these were compiled, the men's serial numbers had assumed the format that allows one to check the personal data contained on their Attestation Papers, which are online on the website of the Library and Archives Canada, http://www.bac-lac.gc.ca/eng/discover/military-heritage/ first-world-war-1914-1918-cef/pages/search.aspx

38. Desmond Morton, When Your Number's Up: The Canadian Soldier in the First World War (Toronto: Random House, 1993), 278; Tim Cook, At the Sharp End: Canadians Fighting the Great War, 1914-1916 (Toronto: Viking, 2007), 28-29.

39. Ibid., 28-29.

40. LAC RG150 Acc. No. 1992-95/166 Box 6145-48. Personal Service File, H.F.V. Meurling.

41. See note 9. [Meurling], "Yukon Motor Machine Gun Battery," biographical note.

42. G.S. Hutchison, Machine Guns: Their History and Tactical Employment (Being also a History of the Machine Gun Corps) (London: MacMillan, 1938), esp. 119-178; Paul Cornish, Machine Guns and the Great War (Barnsley, Yorkshire: Pen and Sword), 55-75.

43. War Diary, Yukons, Appendix I, Preliminary Operation Order no. 24, 1 Oct 1916.

44. Ibid., entry for 21 Oct 1916.

45. Ibid., October 1916, Appendix X, OC. Yukons to 4th Div., 24 Oct 1916, Report on Operations of 21-22 Oct.

46. LAC MG30 E69 General David Watson, Diary, III, 22 Oct 1916.

47. G.W.L. Nicholson, The Canadian Expeditionary Force, 1914-1919: Official History of the Canadian Army in the First World War (Montreal \& Kingston: McGill-Queen's University Press, 2015), 193.

48. War Diary, Yukons, Nov 1916, Appendix III, Capt. H.F. Meurling, “Report on Operations 9.10 and night of 10/11, 1916."

49. Nicholson, Canadian Expeditionary Force, 198. 